\title{
Molecular study of extended-spectrum beta-lactamase (TEM-1) gene in Escherichia Coli isolates collected from Ostad Alinasab Hospital in Tabriz Iran
}

\author{
Iran Tebriz Ostad Alinasab Hastanesi'nin örneklerinden elde edilen Escherichia coli izolatlarında \\ genişletilmiş-spektrum beta-laktamoz (TEM1) geninin araştırılması
}

Azizeh Shadi DİZAJI, Reza Fathi, Abolfazl Jafari SALES

\begin{abstract}
Objectives: Emergence of antibiotic resistance is an important problem in microbial infection control. Certain enzymes can lead to resistances against the third generation cephalosporins by the hydrolysis of monobactams. This study was conducted to evaluate antibiotic sensitivity profiles and the presence of bla $_{T E M}$ gene in $E$. coli isolates collected from clinical specimens of Ostad Alinasab Hospital in Tabriz.
\end{abstract}

Materials and Methods: E. coli (100 isolates) were detected by using conventional bacteriologic tests and then antibiotic sensitivity tests were performed according to Kirby-Bauer method. Confirmatory test was also performed by combined disk test method. Finally bla ${ }_{T E M}$ gene was detected by using polymerase chain reaction (PCR) technique.

Results: Our fo 100 E. coli $23 \%$ of isolates contained bla gene. $18 \%$ of isolates were resistant to ceftazidime, while $30 \%$ of isolates were resistant to cefotaxime and the remaining was sensitive. $46 \%$ of isolates were ESBL producers from which $23 \%$ of them contained $b l a_{T E M}$ gene.

Conclusion: High resistance of $E$. coli isolates to the third generation cephalosporins underlines need for accurate sensitivity tests, also avoidance from inappropriate use of antibiotics.

Keywords: Extended-spectrum beta-lactamases (ESBLs), bla ${ }_{T E M}$ gene, Escherichia coli, Polymerase chain reaction

Azizeh Shadi Dizaji

Department of Microbiology, School of Medicine, Islamic Azad University, Urmia, Iran

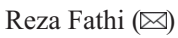

Department of Physiology, School of Medicine, Marmara University, Istanbul, Turkey

e-mail:dr.r.fathi@gmail.com

Abolfazl Jafari Sales

Young Researchers and Elite Club Ahar Branch, Islamic Azad University, Ahar, Iran

Submitted/Gönderilme: 21.11.2015 Accepted/Kabul: 18.12.2015
ÖZ

Amaç: Antibiyotik direncinin gelişmesi bakteriyel enfeksiyonların kontrolünde önemli bir sorundur. Bu çalışma, antibiyotik duyarlılık profillerini değerlendirmek ve Tebriz'de Ostad Alinasab Hastane'sinin klinik örnekleriden elde edilen E.coli izolatlarında bla $_{\text {TEM }}$ geni varlığını değerlendirmek amacıyla planlanmıştır.

Gereç ve Yöntemler: E. coli (100 izolatları) geleneksel bakteriyolojik testler ile elde edilmiş ve daha sonra antibiyotic duyarlılık testleri Kirby-Bauer yöntemine göre değerlendirilmiştir. Doğrulayıcı testler ise "Combinde disk" testleri ile gerçekleştirilmiştir. Son olarak bla $a_{T E M}$ geni varlığı polymeraz zincir reaksiyon (PCR) tekniği kullanılarak değerlendirilmiştir.

Bulgular: Yüz E. coli izolatından \%23'nün blaTEM genini içerdiği belirlenmiştir. İzolatlarının \%18'inde Seftazidim, \% 30 'unda sefotaksim direnci saptanmıştır. Izolatların \% 46'sında EBSL sentezi belirlenmiş ve bu izolatların \% 23'de de blaTEM geninin varlığı saptanmıştır.

Sonuç: E. coli izolatlarında saptanan üçüncü kuşak sefalosporinlere karşı yüksek direnç uygunsuz antibiyotik kullanımından kaçınılması gerektiğinin ve tedavi öncesi doğru duyarlılık testlerinin uygulanması gerektiğinin önemin göstermektedir.

Anahtar kelimeler: Geniş spektrum beta-laktamaz (GSBL), blaTEM geni, Escherichia coli, Polimeraz zincir reaksiyonu

\section{Introduction}

Since sulfonamides and penicillin first appeared, a new opportunity was created in treatment of diseases. In the early days of application of these medicines, they could suppress numerous pernicious epidemics. However, diseases resulting from infectious organisms still remain as a serious challenge $[1,2]$. There are two important mechanisms through which resistance to antibiotics and other medicines emerge. The first one occurs as a result of a spontaneous mutation at approximately $10^{-5} \mathrm{~Hz}$, which alters sensitivity to medicine, 
changes it into a merely selective agent and enables tolerant organisms to survive [1-3]. The second mechanism is to create resistance in genetic exchange wherein genetic information can control bacterial resistance transferred from a (resistant) cell to another (sensitive) by transformation, conjugation and transduction [2-4]. Hospitalized patients are exposed to hospital infections particularly organisms resistant to some medicines (gram negative bacillus species) as a major infection agent and its associated fatality $[1,4]$. Since antibiotics are especially prescribed in intensive care units (ICU) to accelerate the natural treatment process, the problem become more serious, thus, having hydrolysis potential, a wide variety of extended-spectrum beta-lactamases (ESBLs), ESBL-generating strains (Beta-lactamase) used in clinics are of critical importance. ESBL-generating bacteria together with AmpC-encoded class $\mathrm{C}$ cephalosporinase are the most common resistance mechanism of gram positive bacillus to this antibiotic [5-7]. Since the second half of 1980s, when ESBLs and their widespread geographic distribution of these enzymes, they were introduced as an epidemiological phenomenon [8]. This paper focuses on clinical isolates of $E$. coli collected from Ostad Alinasab Hospital in Tabriz in order to propose a sensitivity pattern to the analyzed antibiotics and to study their molecular structure to check presence of $b l a_{T E M}$ from ESBLs.

\section{Materials and Methods}

Various clinical specimen including mucus, urine, blood, tracheal tube secretions, wound secretions, throat secretions, catheter, cerebro spinal fluid, ascites, and peritoneal fluid were collected from hospitalized and outpatients of Ostad Alinasab Hospital in Tabriz by Simple Random Sampling method.

The bacteria extracted from patients' specimen were purified using MacConkey Agar, Blood Agar. Then, they were identified routinely by using citrate, urea, MR, VP, Triple Sugar Iron Agar (TSI) and SIM culture (all culture media were made by Merck) [9].

\section{Combined Disk Test}

This test was conducted by using ceftazidime disk $(30 \mu \mathrm{g})$, cefotaxime $(30 \mu \mathrm{g})$, ceftazidime/clavulanic acid $(30 \mu \mathrm{g} / 10 \mu \mathrm{g})$ and cefotaxime/clavulanic acid $(30 \mu \mathrm{g} / 10 \mu \mathrm{g})$ made in Mast Company. To conduct this test, suspension isolates equal to $0.5 \mathrm{McFarland}$ standard turbidity were prepared. They were, then cultured by cotton swabs on Muller Hinton Agar in three orientations, and the aforementioned disks were superimposed. Growth inhibition zone around the disks were recorded after 24 hour incubation at $37^{\circ} \mathrm{C}$. over $5 \mathrm{~mm}$ increase in the size of growth inhibition zone around ceftazidime/ clavulanic acid $(30 \mu \mathrm{g} / 10 \mu \mathrm{g})$ and cefotaxime/clavulanic acid $(30 \mu \mathrm{g} / 10 \mu \mathrm{g})$ in comparison to that of ceftazidime disks $(30 \mu \mathrm{g})$ and cefotaxime $(30 \mu \mathrm{g})$ indicated ESBL samples are positive and the result proved positive (Fig1.1). In this test, negative control strain was E. coli ATCC 25922 and negative control strain was E. coli ATCC 35218 [9].

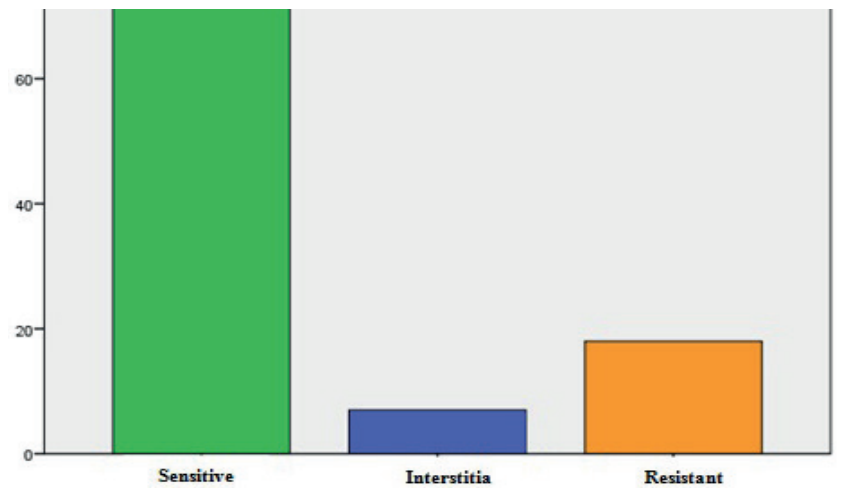

Diag. 1.1- Sensitivity test of $E$. coli isolates to ceftazidime using Disk Agar Diffusion

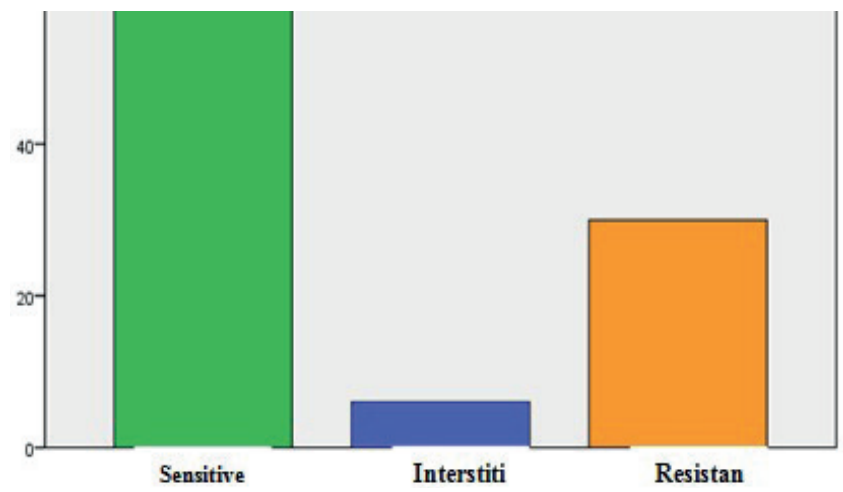

Diag. 1.2- Sensitivity test of E. coli isolates to cefotaxime using Disk Agar Diffusion

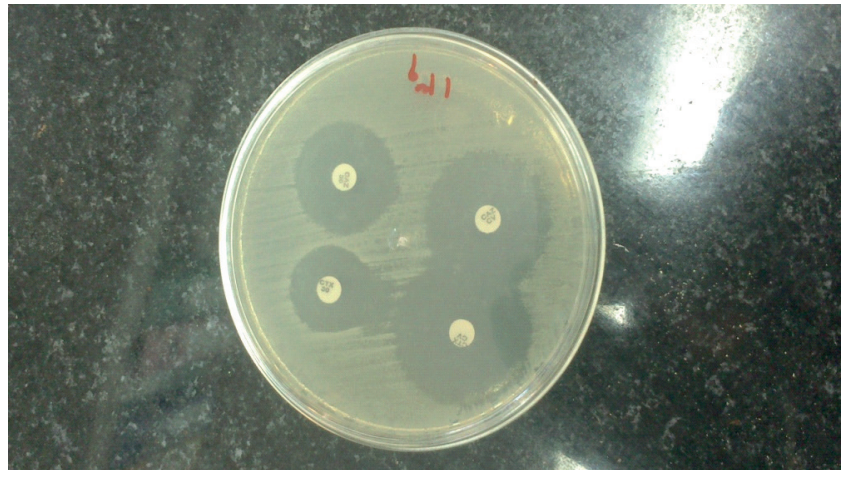

Figure1.1. Schematic representation of increase in the size of growth inhibition zone in E. coli isolates using Combined Disk method for isolate no. 139 . 


\section{DNA Isolation and PCR Cloning:}

First, DNA plasmids were isolated by using Bioneer Kit based on the guidelines of the manufacturing company (RTP ${ }^{\circledR}$ Bacteria DNA Mini Kit). Then, polymerase chain reaction (PCR) test was conducted to identifiy beta lactamase bla $_{\text {TEM }}$ under the following circumstances (Table I). Table II shows the primers used in PCR analysis. Also, negative control strain was E. coli ATCC 25922 and negative control strain was E. coli ATCC 35218. Poly acryl amid gel \%12 and SMO323 Ladder (Fermantase as Size Marker) were used to electrophorese PCR products [10-12].

Table I. Terms used in PCR

\begin{tabular}{lcc}
\multicolumn{1}{c}{ Test procedure } & $\begin{array}{r}\text { Temperature } \\
\left({ }^{\circ} \mathbf{C}\right)\end{array}$ & Time \\
\hline Initial denaturation step & 94 & $4 \mathrm{~min}$ \\
Denaturation step & 94 & $1 \mathrm{~min}$ \\
$\begin{array}{l}\text { Annealing step } \\
\begin{array}{l}\text { Extension/elongation } \\
\text { step }\end{array}\end{array}$ & 53 & $45 \mathrm{~min}$ \\
$\begin{array}{l}\text { Final extension/ } \\
\text { elongation step }\end{array}$ & 72 & $10 \mathrm{~min}$ \\
& & \\
Number of cycles & 35 & \\
\hline
\end{tabular}

Table II. Primers used in PCR reactions for beta lactamase gene type TEM (M.pornour et al 2010)

\begin{tabular}{ll}
\hline Gene sequence & Nucleotide sequence \\
\hline Forward - & ACA TGG GGG ATC ATG \\
TACT-3 - & 5 \\
Reverse - & 5- GAC AGT TAC \\
& AAT GCT TACT-3 \\
\hline
\end{tabular}

\section{Results}

A hundred isolates of E. coli consisted of the following numbers of samples: 80 urine $(80 \%), 10$ tracheal tube secretions $(10 \%), 7$ blood culture (7\%), 1 catheter $(1 \%)$,
1 pleural fluid (1\%), and 1 mucus (1\%). 18 isolates (18\%) were ceftazidime-resistant, 30 were cefotaxime-resistant and the rest were sensitive. Also, 46 isolates (46\%) were ESBL-positive. Of 100 isolates tested for PCR, 23 (23\%) contained $b l a_{T E M}$. In this paper, an isolate containing bla $\mathrm{T}_{\mathrm{TEM}}$ was identified, which was ESBL negative (Figure 2.).

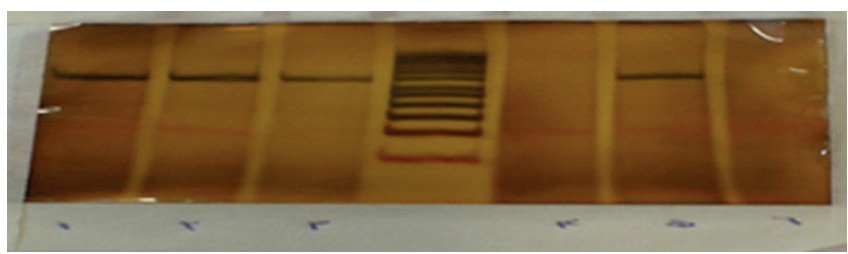

Figure2.1. Results of PCR reaction in search for positive control (no.3) and negative control (no.4) bla $a_{T E M}$ gene

Nos.2, 1, 5 contain bla TEM $_{\text {gene }}$

No.6 lacks bla $a_{T E M}$ gene

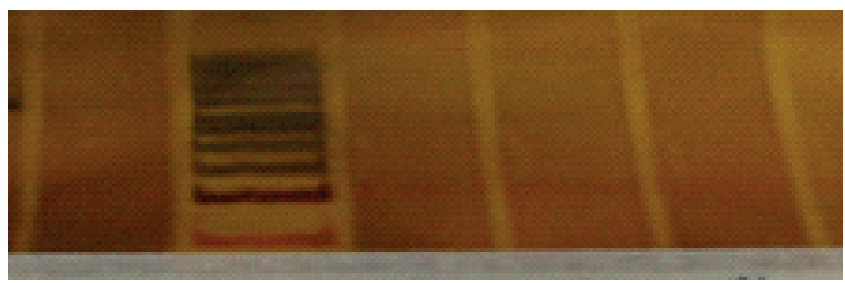

Figure2.2. schematic representation of $b l a_{T E M}$ containing isolates No.7 contains blaTEM gene and Nos. 12, 11, 10, 9, 8 lack it

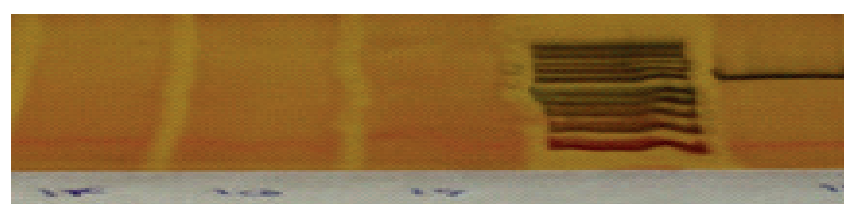

Figure2.3. schematic representation of blaTEM containing isolates Nos.18, 17, 13 contains blaTEM gene and Nos. 16, 15, 14 lack it

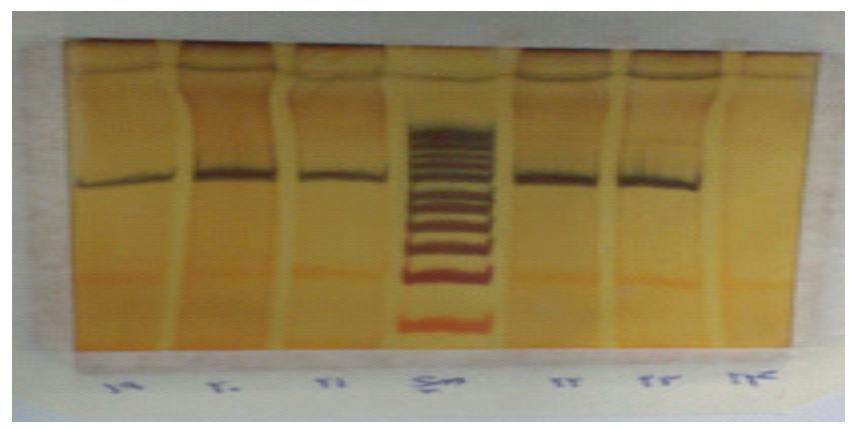

Figure2.4. schematic representation of blaTEM containing isolates Nos.23, 22, 21, 20, 19 contain blaTEM gene and No.24 lacks it

Thorough examinations of E.coli isolates suggested that for ceftazidime: of $23 \mathrm{bla}_{\mathrm{TEM}}$-containing isolates, 20 $(86.9 \%)$ were resistant and 3 were sensitive (13.1\%). For 
cefotaxime: of of $23 \mathrm{bla}_{T E M}$-containing isolates, 21 (88.89\%) resistant and 6 sensitive (13.1\%). Of 100 tested E. coli, one isolate was $b l a_{T E M}$-lacking and cefotaxime-resistant (2.44\%) and 2 lacked $b l a_{T E M}$ with intermediate resistance (4.88\%). For ceftazidime / clavulanic acid, of 23 tested isolates containing $b l a_{T E M}, 21$ showed increase in the size of growth inhibition zone (91.3\%). For cefotaxime / clavulanic acid, of 23 tested isolates containing bla $_{\text {TEM }}, 20$ showed increased growth inhibition zone (91.3\%). Of 100 E.coli isolates tested, one blaTEM-containing isolate showed no increase when exposed to either ceftazidime / clavulanic acid or cefotaxime / clavulanic acid (Figure 1)

\section{Discussion}

Extended-spectrum beta-lactamases (ESBLs) are able to hydrolyze most commonly used beta-lactam antibiotics. Therefore, they are referred to as ESBLs. Seemingly, ESBLs are inherently produced by class $\mathrm{C}$ chromosomal gene cephalosporinase (Ampc) and participate in creating resistance mechanisms in gram negative bacteria. Given these descriptions, ESBLs are class A or D beta lactamase molecules that can hydrolyze oxy-imino-cephalosporins $10 \%$ or more than that of benzylpenicillin. The organisms carrying these genes increase pathogenicity $[1,9]$.

In a similar study conducted by Mazinani and colleagues in 2008 in Vali Asr Hospital, Tehran, 47 isolates of 76 clinical samples (60\%) contained TEM gene [13]. Masjedian showed that, $84.6 \%$ of 148 E.coli strains contained TEM isolates [14]. Mirsalehian et al. suggested that $39.45 \%$ of E.coli strains contained beta lactamase TEM isolates [15]. A comparison made between the present study and above studies indicates high prevalence of this enzyme type in E.coli strains in Iran. A study performed by Bradford in the United States showed that TEM beta lactamase has the highest abundance of ESBLs enzymes $[15,16]$.

Between 2001 and 2006, Hong Fang showed that among 87 E.coli isolates phenotypically known as ESBL producers in Sweden, 63\% had beta lactamase genotype [17], while in the present paper $46 \%$ of the isolates were ESBL positive and $50 \%$ of ESBL producers had a TEM type genotype. In Spain, Emilio David Valverde revealed that $30 \%$ of E.coli samples taken from 11272 patients of Salamanca Hospital produced ESBLs, which TEM family was $22.1 \%$ [18]. However, recent literature increased levels of ESBLs throughout the world. For example, distribution of ESBLs was as follows: Northern America: K. pneumonia (4.2\%-4.4\%), E. coli (3.3\%-4.7\%), P. mirabilis (3.1\%-4.7\%). Far-East-Western region: K. Pneumoniae (11.3\%-51\%), E. coli (9.9\%-23.6\%), Salmonella (3.4\%) and P. mirabilis (1.8\%). Europe: expansion and prevalence of ESBL in Enterobacteriaceae in 1610 E.coli and 785 K. pneumoniae specimen collected from 31 stations of 10 European countries varied from 1\%-5\% in Northern Europe (Germany) to almost 39\%-47\% in East Europe (Russia, Poland, Turkey). In a joint study compiled by Paul-Ehrlich-Gesellschaft (PEG) in 2001, protein extracts from $8.2 \%$ of $K$. pneumonia, $0.8 \%$ of 612 E.coli, and $1.3 \%$ of $152 \mathrm{~K}$. oxytoca specimen contained ESBL $[8,9,19]$, while ESBL was $46 \%$ in the present paper. Overconsumption of antibiotics particularly ceftazidime, hospitalization in ICU wards, and excessive uses of urinary catheter are all factors of breaking out ESBLs. The results of research in recent years on ESBL producing E.coli various strains in different countries are: Pakistan 53.3\% (2006), India 68\% (2002), Spain 51.8\% (2005), South Korea 9.2\% (2004), Lebanon $13.3 \%$ (2005), Israel 22\% (2005), Germany 10.3\% (2005), France 4\% (2006), Turkey 17\% (2004), Bangladesh 43.2\% (2004), United States 2\%-10\% (2003), China 13\%-35\% (2002) [20] .

Eslamy et al studied breakout of extended-spectrum beta-lactamases (ESBLs) on 200 isolates of E. coli collected from hospitals in Arak City by combined disk phonotypical method, which suggested that $47 \%$ ESBL were positive [9], similar to the present paper. Pornour et al (2010) classified 41 E.coli isolates in terms of resistance to medications: $87.8 \%$ resistant to Aztreonam, $80.49 \%$ to piperacillin/tazobactam and ceftazidime, $78.05 \%$ to cefotaxime, cefuroxime and ceftriaxone, $65.85 \%$ to cefepime, and $4.88 \%$ to amikacin. But none of these isolates resisted Imipenem. Also, 97.56\% of ESBL was positive and 36 out of 41 isolates under PCR reaction $(87.8 \%)$ contained TEM beta lactamase gene. In our research, the resistance to Ceftazidime and Cefotaxime were $86.9 \%$ and $88.89 \%$, respectively (20). Soltandallal et al (2010) found that $57.8 \%$ of 200 E.coli isolates contained TEM genes [21]. Zaman zad and colleagues (2008) reported that abundance of TEM-1 genes of E.coli is $48.7 \%$ among 83 isolates of intestinal bacteria producing ESBL including E.coli strains, K. pneumonia and entrobacter from clinic specimen taken from educational hospitals in Shar e Kord $[22,23]$. This was $50 \%$ in our research. In Taiwan, Chinfulin et al. (2010) reported the prevalence of TEM gene in 69 E.coli isolates [24]. Shazi shaki et al (2010) reported that TEM is the most common resistance gene in E.coli of Neonatal Intensive Care Units (NICU) of Indian hospitals $[2])$. 


\section{Conclusions}

We found out that $86.9 \%$ and $\% 88.89$ bla $_{\mathrm{TEM}}$ containing E.coli isolates resisted ceftazidime and cefotaxime, respectively. This represents the role of $b l a_{T E M}$ gene in making resistance to cephalosporins. With regard to growing increase of various types of ESBL enzymes and their unbalanced effects on various antibiotics, precise determination of different types of TEM enzyme and other ESBL enzymes using other molecular methods including PCR-RFLP, REP-PCR and sequencing these genes is inevitable. Beta lactam-based antibiotics specially, third generation of cephalosporins are the main antibiotic therapies in clinical centers. It should be noted that increased resistance of pathogenic bacteria to these medications particularly ceftazidime and cefotaxime (for E.coli) questions the clinical effect of such medications. Thus, prescription of antibiotics suited to precise sensitivity test are recommended to avoid expansion of this medicinal resistance, ESBL secretion, and infections with likely ESBL-producing organisms.

\section{References}

1. Joklik WK, Willett HS, Wilfert C H. (eds) Antimicrobial agents. Zinsser Microbiology. 20th ed. Norwalk: Appleton and Lange, 2005: 153-87.

2. Al-Jasser A M. Extended-spectrum beta-lactamases (ESBLs): A global problem.Kuwait Med J 2006;38;171-85.

3. Medeiros A A. Evolution and dissemination of ß-lactamases accelerated by generations of $ß$-lactam antibiotics. Clin Infect Dis 1997;997:(Suppl 1):S19-45.

4. Koseoglu O, Kocaguz S, Gur D, Akova M. Nosocomial blood stram infection in Turkish university hospital : Study of Gramnegative bacilli and their sensitivity patterns, Int J Antimicrob Agents 2001;17:477-81.

5. Rupp M E, Fey P D. Extended - spectrum beta-lactamse (ESBL) producing Enterobacteriaceae: Consideration for diagnosis, prevention and drug treatment. Drugs 2003;63:35365.

6. Thomson K D, Preevan AM, Sanders CC. Novel plasmedmediated beta- lactamases in Enterobacteriaceae: emerging problems for new beta-lactam antibiotic. Curr Clin Top Infect Dis 1996;16:151-63.

7. Ensor VM, Livermore DM, Hawkey PM. A novel reverseline hybridization assay for identifying genotypes of $C T X-M$ Typeextended-spectrum beta-lactamases. Antimicrob Chemother 2007;59:387-95.

8. Biedenbach DJ, Lewis MT, Gones RN. Invitro evaluation of cefepime and other road-spectrum p-Iactams for isolates in Malaysia and Singapore Antimicrobial Resistance Study group. Diagn Microbiol Infect Dis 1999;35:277- 83.

9. Stürenburg E, Mack D. Extended-spectrum beta-lactamases: implications for the clinical microbiology laboratory, therapy, and infection control. J Infect 2003;47:273-95.

10. Lal P, Kapil A, Das B K, Sood S. Occurrence of TEM and
SHV gene in extended-spectrum beta- lactamases ( ESBLS ) producing Klebsiella sp. Isolated from a tertiary care hospital. Indian Med Res 2007;125:173-8.

11. Colom K, Perez J, Alonso R, Aranguiz AF, Larino E, Cisterna R. Simple and reiable multiplex PCR assay for detection of blaTEM genes in Enterobacteriaceae. FEMS Microbiol Lett 2003;223:147-51.

12. Zamberi S, Rusmah Y, Rusmah M. Extended- spectrum beta- lactamases- producing Escherichia coli from a tertiary hospital in Malaysia: emergence of CTX- M- type betalactamases variation. Res Microbiol 2008;125: 1-5.

13. Hosseini-Mazinani SM, Eftekhar F, Milani M, Ghandili S. Characterization of beta-lactamases from urinary isolates of Escherichia coli in Tehran. Iran Biomed J 2007;11:95-9.

14. Masjedian GF, Valehi F, Talebi A, Rastegar LA. Moulecular evaluation of resistance to espanded antibiotics in Escherichia coli and Klebsiella pneumoniae. Iran J Med Microbiol 2007;1:27-34.

15. Mirsalehian A, Akbari-Nakhjavani F, Peymani A, Kazemi B, JabalAmeli F, Mirafshar SM. Prevalence of extended spectrum -lactamase-producing Enterobacteriaceae by phenotypic andgenotypic methods in intensive care units in Tehran, Iran. Daru 2008;16:169-73.

16. Hernández MS, \%ADa\%20 JA\%225BAuthor\%D\&itool=EntrezSystem.PEntrez. Pubmed.Pubmed ResultsPanel.Pubmed Discovery Panel.Pubmed_RVAbstractPlus"GarcíaHYPERLINK "http://www.ncbi.nlm.nih.gov/sitesentrez?Db=pubmed $\& \mathrm{Cmd}=\mathrm{Search} \& \mathrm{Ter} \mathrm{m}=\% 22 \mathrm{Garc} \% \mathrm{C} 3 \% \mathrm{ADa} \% 20$ JA \% 22\%5 B A uthor\%5 D\&itool=EntrezSystem 2 . PEntrez.Pubmed.Pubmed_ResultsPanel.Pubmed DiscoveryPanel.Pubmed_RVAbstractPlus”JA, \%Boz $\% 20$ JL\%225BAuthor\%D\&itool=EntrezSystem.PEntrez.Pubmed. Pubmed_ResultsPanel.Pubmed_DiscoveryPanel.Pubmed_ RVAbstractPlus"Muñoz JL In vitro activity of fosfomycin against ESBL-producing enterobacteria of urinary origin. Rev Esp Quimioter. 2009;22:25-9.

17. Bradford PA. Extended-spectrum beta-lactamases in the 21stcentury: characterization, epidemiology, and detection of thisimportant resistance threat. Clin Microbiol Rev 2001;14:933-51. doi: 10.1128/CMR.14.4.933-951.2001

18. Fang H, Ataker F, Hedin G, Dornbusch K. Molecular epidemiology of extended-spectrum beta-lactamases among Escherichia coli isolates collected in a Swedish hospital and its associated health care facilities from 2001 to 2006. J Clin Microbiol 2008;46:707-12. doi: 10.1128/JCM.01943-07

19. Pai H, Lee HJ, Choi E H, Kim J, Jacoby GA. Evolution of TEM-related extended-spectrum beta-lactamases in Korea. Anti Microb Agent Chemother 2001;45: 3651-3.

20. Pornour MR, Nahaie Mobaien H, Mobasher Karjedi A. Molecular study of Eutended- Spectrum Beta- Lactamaase (TEM type) in Escherichia coli and Klebsiella pneumoniae isolates from clinical samples, Med J Tabriz Univ Med 2010;32:30-4.

21. Soltan Dallal M M, Molla Aghamirzaei H, Fallah Mehrebadi J, Rastegar Lari A, Sabbaghi A, Eshraghian MR. Molecular detection of TEM and Ampc (OHA, Mox) broad spectrum B- lactamase in clinical isolates. Tehran Univ Med J 2010;68:315-20. 
22. Zamanzad B, Deiham B, molecular detectin of TEM1 type beta- lactamasegenes in Escherichia coli, Klebsiella pnonomoniae, Entr, bacter from clinical Isolated Educational hospitals in Shahrkord. J Hamadan Med Univ 2007;14:27-34.

23. Shojapour M, Shariati L, Karimi A, Zamanzad B. Prevalence of TEM-1 type beta-lactamase genes in Pseudomonas aeruginosa strains isolated from burn infections using Duplex PCR in Shahrekord. 2011:14:55-61.

24. Lin CF, Hsu SK, Chen CH, Huang JR, Lo HH. Genotypic detection and molecular epidemiology of extended- spectrum beta lactamase producing Escherichia coli and Klebsiella pneamoniae in a regional hospital in central Taiwan. J Med Microbiol 2010; 56:665- 71. doi: 10.1099/jmm.0.015818-0.

25. Shakil, SH., Akram, M,. et al, 2010. Acguisition of entendedspectrum- lactomase produsing Escherichia coli strains in male and female infants admitted to a neonatal intensive care unit: molecular epidmiogy and analysis of risk factors, Journal Med microbial. 59: 948-954. 